\title{
Proinsulin and $\mathrm{C}$-peptide at onset and during 12 months cyclosporin treatment of Type 1 (insulin-dependent) diabetes mellitus*
}

\author{
O. Snorgaard, S. G. Hartling and C. Binder \\ Steno Memorial Hospital, Gentofte, Denmark
}

\begin{abstract}
Summary. An increased proinsulin to C-peptide molar ratio at the onset of Type 1 (insulin-dependent) diabetes mellitus has been suggested. We studied fasting proinsulin levels and proinsulin/C-peptide ratios in the newly diagnosed diabetic subjects participating in the Canadian/European placebo controlled cyclosporin study at entry, during the one year treatment period and six months of follow-up. Available entry data from 176 out of the 188 allocated patients were compared to 60 age and weight matched control subjects. Fasting proinsulin was significantly elevated in male patients compared to male control subjects $(p<0.01)$, whereas the levels only tended to be elevated in female patients. The proinsulin/C-peptide ratio was three to fourfold elevated in the diabetic groups of both sexes, $(p<0.001)$. Further, proinsulin and C-peptide were studied in 83 cyclosporin and 86 placebo-treated subjects during the trial and follow-up. An additional increase of proinsulin/C-peptide ratio was observed during the first three months of placebo treatment. It remained constantly high for nine months and then declined to entry level. This pattern was not seen in the cyclosporin-
\end{abstract}

treated group, where the ratio was unchanged during the 12 months trial and follow-up. The effect of cyclosporin on the induction of non-insulin requiring remission was unrelated to fasting and glucagon stimulated C-peptide levels at entry, whereas $64 \%$ of the cyclosporin-treated against $28 \%$ of the placebo-treated subjects $(p<0.01)$ went into remission if the proinsulin/C-peptide ratio at entry was above 0.024 . If the ratio was below 0.024 at entry, $42 \%$ and $33 \%$ went into noninsulin requiring remission, respectively (NS). We conclude that fasting proinsulin to $\mathrm{C}$-peptide molar ratio is elevated at the onset of Type 1 diabetes mellitus. A further plateaushape elevation lasting nine months was seen during the remission period. Cyclosporin seems to inhibit or delay this development. The proinsulin/C-peptide ratio at diagnosis may show to be of value in the prediction of remission during cyclosporin treatment.

Key words: Type 1 (insulin-dependent) diabetes mellitus, recent-onset, proinsulin, C-peptide, cyclosporin, remission.
Characteristic quantitative changes of B-cell function are seen at onset and during the first year of remission and relapse of Type 1 (insulin-dependent) diabetes mellitus [1-6]. Further, a five to tenfold increase of the molar ratio between proinsulin and C-peptide suggests a qualitatively altered function of the $\mathrm{B}$ cells at the time of diagnosis $[7,8]$. This elevated ratio seems to persist throughout the remission period [8]. The mechanisms behind, and significance of, this alteration of B-cell function is unknown.

In recent years clinical trials of cyclosporin in newly diagnosed Type 1 diabetes, including the present study, have shown a beneficial effect of cyclosporin on the

* Prepared by the authors for The Canadian/European Diabetes Study Group. frequency of non-insulin requiring remission and on C-peptide levels $[9,10]$. The effect of cyclosporin on proinsulin levels is unknown.

Ludvigsson [8] found a weak correlation between a long remission and a low proinsulin/C-peptide ratio at onset, suggesting a possible value of the ratio as a predictor of remission. Old age, high C-peptide levels and low islet cell antibody titres at diagnosis are suggested as having predictive value on the rate of fall of C-peptide levels and the frequency of remission [3-6].

We studied fasting proinsulin and C-peptide levels of the recent onset insulin-treated Type 1 diabetic subjects participating in the Canadian/European randomized placebo controlled trial of cyclosporin [9]. Primarily, we analysed the quantitative and qualitative changes of B-cell function at entry of the study. Secondly we studied the further changes of the molar ratio of proinsulin to 
Table 1. Characteristics of 134 male and 42 female recent onset Type 1 (insulin-dependent) diabetic subjects and 30 male and $30 \mathrm{fe}$ male age and weight matched control subjects. Results are indicated as median, 25 th and 75 th percentile

\begin{tabular}{|c|c|c|c|c|c|c|}
\hline & \multicolumn{3}{|l|}{ Males } & \multicolumn{3}{|l|}{ Females } \\
\hline & $\begin{array}{l}\text { Diabetic } \\
\text { subjects }\end{array}$ & $\begin{array}{l}\text { Control } \\
\text { subjects }\end{array}$ & $p$ & $\begin{array}{l}\text { Diabetic } \\
\text { subjects }\end{array}$ & $\begin{array}{l}\text { Control } \\
\text { subjects }\end{array}$ & $p$ \\
\hline Number & 134 & 30 & & 42 & 30 & \\
\hline Age (years) & $\begin{array}{l}22 \\
(17-26)\end{array}$ & $\begin{array}{l}21 \\
(14-30)\end{array}$ & NS & $\begin{array}{l}22 \\
(18-24)\end{array}$ & $\begin{array}{l}20 \\
(15-25)\end{array}$ & NS \\
\hline Weight (kg) & $\begin{array}{l}66 \\
(59-73)\end{array}$ & $\begin{array}{l}70 \\
(46-79)\end{array}$ & NS & $\begin{array}{l}55 \\
(50-60)\end{array}$ & $\begin{array}{l}56 \\
(50-65)\end{array}$ & NS \\
\hline $\begin{array}{l}\text { Fasting } \\
\text { C-peptide } \\
\text { (nmol/l) }\end{array}$ & $\begin{array}{l}0.20 \\
(0.15-0.26)\end{array}$ & $\begin{array}{l}0.38 \\
(0.31-0.45)\end{array}$ & $<0.001$ & $\begin{array}{l}0.21 \\
(0.17-0.27)\end{array}$ & $\begin{array}{l}0.42 \\
(0.30-0.49)\end{array}$ & $<0.001$ \\
\hline $\begin{array}{l}\text { Fasting } \\
\text { proinsulin } \\
\text { (pmol/1) }\end{array}$ & $\begin{array}{l}5.1 \\
(1.8-11)\end{array}$ & $\begin{array}{l}2.5 \\
(1.7-4.1)\end{array}$ & $<0.01$ & $\begin{array}{l}3.9 \\
(1.5-8.7)\end{array}$ & $\begin{array}{l}3.1 \\
(1.4-5.5)\end{array}$ & NS \\
\hline $\begin{array}{l}\text { Proinsulin/ } \\
\text { C-peptide } \\
\text { ratio (\%) }\end{array}$ & $\begin{array}{l}2.6 \\
(1.3-5.1)\end{array}$ & $\begin{array}{l}0.70 \\
(0.37-1.3)\end{array}$ & $<0.001$ & $\begin{array}{l}2.1 \\
(0.96-3.5)\end{array}$ & $\begin{array}{l}0.73 \\
(0.38-1.1)\end{array}$ & $<0.001$ \\
\hline $\begin{array}{l}\text { C-peptide } \\
6 \text { min after i.v. } \\
\text { glucagon } \\
(\mathrm{nmol} / 1)\end{array}$ & $\begin{array}{l}0.35 \\
(0.25-0.48)\end{array}$ & & & $\begin{array}{l}0.32 \\
(0.27-0.40)\end{array}$ & & \\
\hline $\begin{array}{l}\text { Proinsulin } \\
6 \text { min afteri.v. } \\
\text { glucagon }\end{array}$ & $\begin{array}{l}6.1 \\
(2.0-12)\end{array}$ & & & $\begin{array}{l}4.7 \\
(2.0-9.1)\end{array}$ & & \\
\hline $\begin{array}{l}\mathrm{Hb} A_{1 \mathrm{c}} \\
(\%)\end{array}$ & $\begin{array}{l}10.7^{\mathrm{a}} \\
(9.3-12.2)\end{array}$ & & & $\begin{array}{l}9.4^{\mathrm{a}} \\
(8.7-10.5)\end{array}$ & & \\
\hline $\begin{array}{l}\text { Fasting } \\
\text { blood glucose } \\
(\mathrm{mmol} / \mathrm{l})\end{array}$ & $\begin{array}{l}7.9 \\
(6.1-11.1)\end{array}$ & & & $\begin{array}{l}7.4 \\
(6.1-9.1)\end{array}$ & & \\
\hline $\begin{array}{l}\text { Insulin dose } \\
\text { per } \mathrm{kg}\end{array}$ & $\begin{array}{l}0.48 \\
(0.34-0.64)\end{array}$ & & & $\begin{array}{l}0.48 \\
(0.35-0.58)\end{array}$ & & \\
\hline
\end{tabular}

${ }^{a}$ Males vs females, $p<0.05$

C-peptide during the following remission together with the effect of cyclosporin on the ratio. Thirdly, the possible value of the proinsulin/C-peptide ratio in the prediction of remission was considered.

\section{Subjects and methods}

A group of 188 newly diagnosed ketosis-prone Type 1 diabetic patients were consecutively admitted to 12 diabetic centers in Canada and Europe for a randomized placebo controlled trial of cyclosporin. Insulin treatment was started prior to allocation. Patients were included within 14 weeks of the onset of symptoms and 6 weeks of insulin treatment. Obesity, a strong family history of Type 2 (non-insulin-dependent) diabetes or conditions excluding cyclosporin treatment were exclusion criteria. The intention was to treat for 12 months, but placebo was substituted for cyclosporin, if two consecutive fasting C-peptide measurements were less than $0.1 \mathrm{nmol} / \mathrm{l}$, after the third month. Proinsulin and C-peptide were measured in the fasting state and $6 \mathrm{~min}$ after i. v. injection of $1 \mathrm{mg}$ of glucagon at entry of the study and at $1,3,6,9,12,15$ and 18 months.

HLA-DR type was determined in all subjects. Islet cell and insulin antibodies were measured at entry, 3, 6, 9 and 12 months. Fasting blood glucose ( $\mathrm{fBG}$ ) and $\mathrm{Hb} \mathrm{A}_{1 \mathrm{c}}$ were measured at all time points, but were only available for us at entry. For further details consult the principal report of the trial [9].
C-peptide in plasma was analysed in two different laboratories using the same RIA techniques according to Heding [11] and Faber [12] with a good correlation $(r=0.96)$. Proinsulin was analysed with an enzyme linked immunoassay [13]. Detection limit was $1.2 \mathrm{pmol} / \mathrm{l}$. Below that, the figure $1.1 \mathrm{pmol} / \mathrm{l}$ was given. C-peptide did not crossreact up to a concentration of $10,000 \mathrm{pmol} / \mathrm{l}$ and insulin not up to 400 $\mathrm{pmol} / \mathrm{l}$ at $50 \%$ dilution. Both intact proinsulin and major split products were measured. The islet cell antibody titres were measured using workshop methodology as recently described in detail [14].

A group of 60 normal subjects were selected from a pool of 176 healthy non-diabetic subjects. All were without first degree Type 1 diabetic relatives. Selection criteria was an age range of 9 to 35 years and a body mass index below $25 \mathrm{~kg} / \mathrm{m}^{2}$.

\section{Statistical analysis}

C-peptide and proinsulin results are indicated as median, 25th and 75 th percentile. Between-group comparisons were made with Mann-Whitney Rank Sum Test, and within-group with Wilcoxon Test for Pair Differences. $\log _{e}$ (proinsulin) and $\log _{e}$ (proinsulin/Cpeptide ratio) were used as dependent variables in the analyses of variance and in the regression analyses. Only complete records were entered in the former, $n=113$ (proinsulin) and $n=112$ (proinsulin/C-peptide ratio). BMDP software programmes (version 1987, Los Angeles, Calif., USA) were used for the statistical analyses.

\section{Results}

\section{Prior to cyclosporin treatment}

Plasma from the time of entry to the study were available from 176 of the 188 diabetic subjects for proinsulin and Cpeptide measurements. The characteristics of these patients and the 60 normal subjects are indicated in Table 1. The two groups were matched with regard to age and weight when considering the two sexes separately.

Fasting proinsulin was approximately doubled $(p<0.01)$ and fasting C-peptide approximately halved $(p<0.001)$ in the male insulin-treated patients at entry compared to the normal male subjects (Table 1), leading to a markedly elevated proinsulin/C-peptide ratio, $p<0.001$. Fasting proinsulin was not significantly elevated in the female group but C-peptide was halved $(p<0.001)$ leading to the same level of increased proinsulin/C-peptide ratio $(p<0.001)$ as in male subjects (Table 1$)$. Comparing the two sexes revealed no significant differences in proinsulin, C-peptide, proinsulin/C-peptide ratio or any other of the available parameters at entry or at any time point during the study, except for the higher weight and a significantly higher $\mathrm{HbA}_{1 \mathrm{c}}$ among male diabetic patients (Table $1, p<0.05$ ). In spite of these minor differences between sexes, the data of both sexes are pooled in Figures 1 and 2 and in the subsequent results.

As is apparent from Figures 1 and 2, the fasting proinsulin and proinsulin/C-peptide ratio cannot be approximated to a normal distribution. However, the $\log _{\mathrm{e}}$ values showed normal distributions with similar shapes in Type 1 diabetic and normal subjects.

Neither fasting proinsulin nor proinsulin/C-peptide ratio at entry of the study were related to age, weight, $\mathrm{HbA}_{1 \mathrm{c}}$, $\mathrm{fBG}$ concentration, insulin dose per $\mathrm{kg}$ or insulin antibodies. Islet cell antibody titres were not correlated to 
proinsulin or proinsulin/C-peptide ratio at any time. Furthermore, there were no significant differences in proinsulin and proinsulin/C-peptide ratio, when dividing the population according to the HLA-DR types, DR $3 / 4$, DR4/X, DR3/X and DRX/X.

Diabetic patients on insulin therapy $\leq 14$ days prior to allocation had significantly lower proinsulin levels and proinsulin/C-peptide ratio at entry. Excluding subjects with $>6$ weeks of symptoms according to the definition used in the principal report [9], these differences disappeared.

Fasting proinsulin was correlated to fasting C-peptide $(r=0.41, p<0.001)$, to glucagon-stimulated C-peptide $(r=0.41, p<0.001)$ and very closely to glucagon-stimulated proinsulin $(r=0.94, p<0.001)$. Thus, the latter has not been considered further in the present study.

\section{Data obtained during cyclosporin or placebo treatment}

Of the 93 patients allocated to cyclosporin and the 95 to placebo, only data from 83 and 86 were included in the present part of the study. The others were either excluded from the original trial or no plasma for proinsulin measurements were available.

Fasting proinsulin, fasting C-peptide, proinsulin/Cpeptide ratio and insulin dose per $\mathrm{kg}$ during the 12 months cyclosporin or placebo treatment are given in Table 2 , together with data from the subsequent six months, when no immunotherapy was given. Proinsulin increased in the placebo group from entry to one month $(p<0.01)$ and from one month to three months $(p<0.001)$. It remained elevated the following nine months and then declined significantly to entry levels $(p<0.01)$. The proinsulin/C-peptide ratio displayed a similar development in this group. A smaller but significant increase of fasting proinsulin was seen during the first three months of cyclosporin $(p<0.01)$, followed by unchanged levels. The ratio did not change from baseline in this group.

Proinsulin/C-peptide ratio was significantly lower during cyclosporin treatment at $3,6,9(p<0.01)$ and 12 months $(p<0.05)$ and fasting proinsulin lower at 3 $(p<0.05)$ and 9 months $(p<0.05)$ (Table 2). The one-way analyses of variance showed a significant treatment effect on proinsulin/C-peptide ratio $(p<0.01)$, but not on proinsulin.

An inverse correlation was found between the mean values of insulin dose per $\mathrm{kg}$ at each time point and the respective $\log _{e}$ (proinsulin) values in both treatment groups, cyclosporin: $r=-0.94, p<0.01$ and placebo: $r=-0.88, p<0.05$. The individual correlations expressed as the median $r$-values were $-0.45(-0.70$ to -0.01$)$ and $-0.43(-0.77$ to -0.11$)$, respectively. However, insulin dose was only correlated to the mean C-peptide values during cyclosporin $(r=-0.97, p<0.01)$, and not during placebo $(r=-0.49$, NS). The individual coefficients of correlation were $-0.55(-0.70$ to -0.25$)$ and -0.34 $(-0.67$ to -0.08$)$, respectively. Insulin dose and $\log _{\mathrm{e}}$ (proinsulin/C-peptide ratio) seem to be better related in the placebo-treated group $(r=-0.62$, individual $r$ values: $-0.40(-0.66$ to -0.07$))$ compared to the cy-

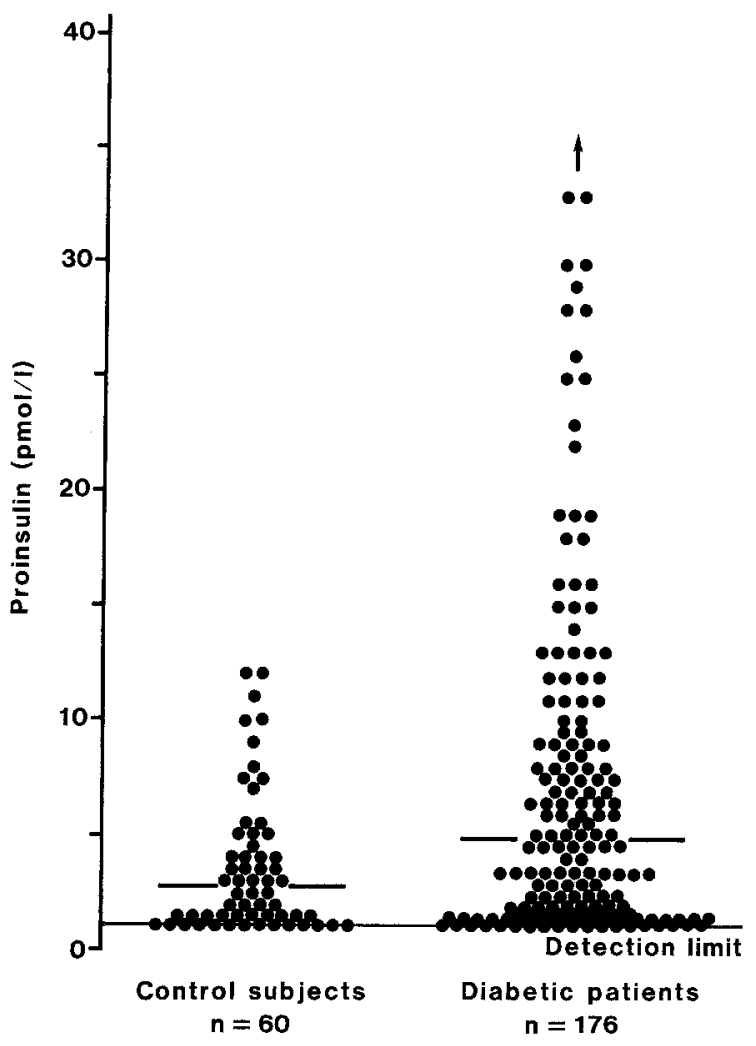

Fig. 1. Fasting proinsulin in 176 recent onset insulin-treated Type 1 (insulin-dependent) diabetic subjects and 60 age and weight matched control subjects. The median value was $4.8 \mathrm{pmol} / \mathrm{l}$ in the Type 1 diabetic group and $2.8 \mathrm{pmol} / \mathrm{l}$ in the control group, (bars) $p<0.01$. Arrow indicates proinsulin values of $44,50,52,71,72$ and $160 \mathrm{pmol} / \mathrm{l}$
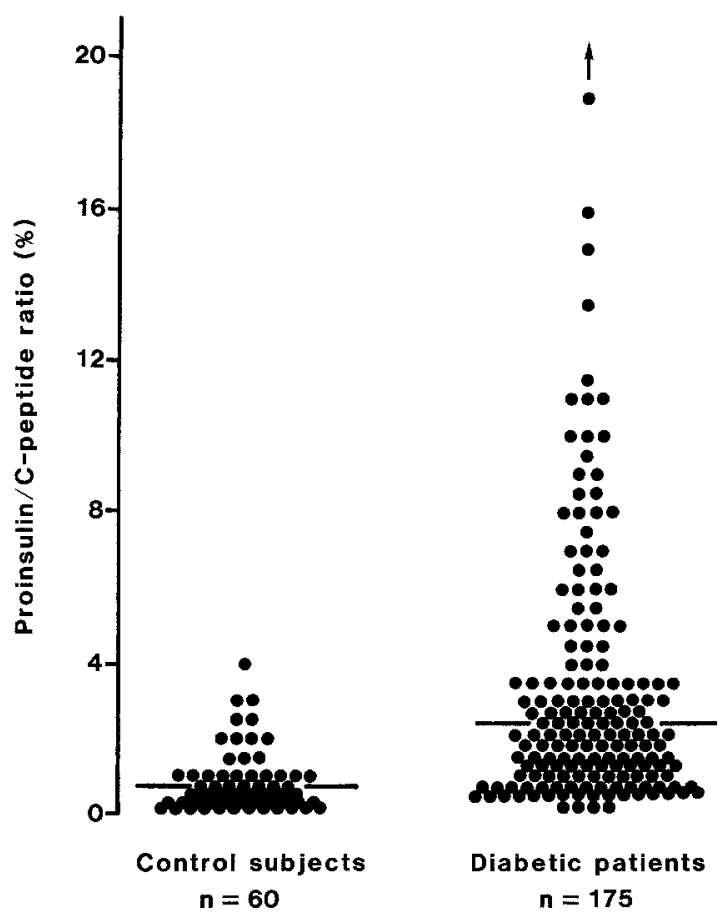

Fig. 2. Fasting proinsulin/C-peptide ratio in 175 recent onset insulintreated Type 1 (insulin-dependent) diabetic subjects and 60 age and weight matched control subjects. The median value was $2.4 \%$ in the diabetic group and 0.72 in the control group (bars), $p<0.001$. Arrow indicates values of $40,55,56$ and $59 \%$ 
Table 2. Fasting proinsulin, C-peptide, proinsulin/C-peptide ratio and insulin dose per $\mathrm{kg}$ during 1 year of treatment with cyclosporin (cy) or placebo (pla) and 6 months follow-up. Median, 25th and 75th percentile

\begin{tabular}{|c|c|c|c|c|}
\hline & $\begin{array}{l}\text { Fasting } \\
\text { Proinsulin } \\
(\mathrm{pmol} / \mathrm{s})\end{array}$ & $\begin{array}{l}\text { Fasting } \\
\text { C-peptide } \\
(\mathrm{nmol} / \mathrm{l})\end{array}$ & $\begin{array}{l}\text { Proinsulin/ } \\
\text { C-peptide } \\
\text { ratio (\%) }\end{array}$ & $\begin{array}{l}\text { Insulin } \\
\text { dose } \\
\text { (U/kg) }\end{array}$ \\
\hline \multicolumn{5}{|l|}{ Baseline } \\
\hline $\operatorname{cy}(n=80)$ & $\begin{array}{l}5.1 \\
(1.6-11)\end{array}$ & $\begin{array}{l}0.19 \\
(0.13-0.26)\end{array}$ & $\begin{array}{l}2.7 \\
(1.4-5.2)\end{array}$ & $\begin{array}{l}0.50 \\
(0.36-0.66)\end{array}$ \\
\hline pla $(n=81)$ & $\begin{array}{l}4.7 \\
(2.0-10)\end{array}$ & $\begin{array}{l}0.21 \\
(0.17-0.27)\end{array}$ & $\begin{array}{l}2.2 \\
(1.1-4.6)\end{array}$ & $\begin{array}{l}0.45 \\
(0.33-0.60)\end{array}$ \\
\hline \multicolumn{5}{|l|}{1 month } \\
\hline cy $(n=74)$ & $\begin{array}{l}7.3 \\
(2.7-13)\end{array}$ & $\begin{array}{l}0.24 \\
(0.16-0.30)\end{array}$ & $\begin{array}{l}3.2 \\
(1.3-4.9)\end{array}$ & $\begin{array}{l}0.33 \\
(0.21-0.49)\end{array}$ \\
\hline pla $(n=73)$ & $\begin{array}{l}7.2 \\
(3.1-16)\end{array}$ & $\begin{array}{l}0.23 \\
(0.19-0.30)\end{array}$ & $\begin{array}{l}2.6 \\
(1.6-6.0)\end{array}$ & $\begin{array}{l}0.29 \\
(0.21-0.44)\end{array}$ \\
\hline \multicolumn{5}{|l|}{3 months } \\
\hline $\operatorname{cy}(n=76)$ & $\begin{array}{l}7.6^{\mathrm{a}} \\
(3.3-14)\end{array}$ & $\begin{array}{l}0.25 \\
(0.20-0.35)\end{array}$ & $\begin{array}{l}2.9^{\mathrm{b}} \\
(1.7-4.7)\end{array}$ & $\begin{array}{l}0.16 \\
(0.00-0.38)\end{array}$ \\
\hline $\operatorname{pla}(n=74)$ & $\begin{array}{l}11.5^{\mathrm{a}} \\
(3.7-25)\end{array}$ & $\begin{array}{l}0.23 \\
(0.19-0.33)\end{array}$ & $\begin{array}{l}5.0^{\mathrm{b}} \\
(2.2-8.9)\end{array}$ & $\begin{array}{l}0.23 \\
(0.00-0.38)\end{array}$ \\
\hline \multicolumn{5}{|l|}{6 months } \\
\hline cy $(n=74)$ & $\begin{array}{l}6.7 \\
(3.1-19)\end{array}$ & $\begin{array}{l}0.27^{\mathrm{b}} \\
(0.21-0.35)\end{array}$ & $\begin{array}{l}2.8^{b} \\
(1.5-6.3)\end{array}$ & $\begin{array}{l}0.09^{\mathrm{b}} \\
(0.00-0.33)\end{array}$ \\
\hline pla $(n=73)$ & $\begin{array}{l}9.7 \\
(5.9-16)\end{array}$ & $\begin{array}{l}0.21^{b} \\
(0.14-0.29)\end{array}$ & $\begin{array}{l}4.9^{b} \\
(3.2-8.5)\end{array}$ & $\begin{array}{l}0.24^{b} \\
(0.11-0.42)\end{array}$ \\
\hline \multicolumn{5}{|l|}{9 months } \\
\hline $\operatorname{cy}(n=62)$ & $\begin{array}{l}6.2^{a} \\
(2.7-14)\end{array}$ & $\begin{array}{l}0.24^{b} \\
(0.19-0.32)\end{array}$ & $\begin{array}{l}2.9^{c} \\
(1.4-5.6)\end{array}$ & $\begin{array}{l}0.19^{b} \\
(0.00-0.36)\end{array}$ \\
\hline $\operatorname{pla}(n=72)$ & $\begin{array}{l}10.5^{\mathrm{a}} \\
(5.9-18)\end{array}$ & $\begin{array}{l}0.17^{b} \\
(0.12-0.30)\end{array}$ & $\begin{array}{l}5.3^{c} \\
(2.8-10.6)\end{array}$ & $\begin{array}{l}0.32^{\mathrm{b}} \\
(0.11-0.47)\end{array}$ \\
\hline \multicolumn{5}{|l|}{12 months } \\
\hline cy $(n=74)$ & $\begin{array}{l}9.0 \\
(3.3-17)\end{array}$ & $\begin{array}{l}0.26^{\mathrm{b}} \\
(0.18-0.34)\end{array}$ & $\begin{array}{l}3.7^{\mathrm{a}} \\
(1.9-5.6)\end{array}$ & $\begin{array}{l}0.20^{\mathrm{b}} \\
(0.00-0.33)\end{array}$ \\
\hline pla $(n=78)$ & $\begin{array}{l}9.9 \\
(3.7-16)\end{array}$ & $\begin{array}{l}0.18^{\mathrm{b}} \\
(0.13-0.27)\end{array}$ & $\begin{array}{l}5.4^{\mathrm{a}} \\
(2.4-8.1)\end{array}$ & $\begin{array}{l}0.36^{\mathrm{b}} \\
(0.20-0.51)\end{array}$ \\
\hline \multicolumn{5}{|l|}{15 months } \\
\hline cy $(n=42)$ & $\begin{array}{l}6.8 \\
(1.1-11)\end{array}$ & $\begin{array}{l}0.23^{\mathrm{a}} \\
(0.14-0.31)\end{array}$ & $\begin{array}{l}2.9 \\
(1.2-4.2)\end{array}$ & \\
\hline pla $(n=41)$ & $\begin{array}{l}3.0 \\
(1.3-9.7)\end{array}$ & $\begin{array}{l}0.16^{\mathrm{a}} \\
(0.10-0.22)\end{array}$ & $\begin{array}{l}2.2 \\
(1.4-4.4)\end{array}$ & \\
\hline \multicolumn{5}{|l|}{18 months } \\
\hline $\operatorname{cy}(n=35)$ & $\begin{array}{l}7.2 \\
(3.0-11)\end{array}$ & $\begin{array}{l}0.20 \\
(0.13-0.26)\end{array}$ & $\begin{array}{l}3.5 \\
(1.9-5.5)\end{array}$ & \\
\hline pla $(n=35)$ & $\begin{array}{l}3.5 \\
(1.1-10)\end{array}$ & $\begin{array}{l}0.13 \\
(0.09-0.23)\end{array}$ & $\begin{array}{l}3.7 \\
(1.6-5.3)\end{array}$ & \\
\hline
\end{tabular}

Cy vs Pla: ${ }^{\mathrm{a}} p<0.05 ;{ }^{\mathrm{b}} p<0.01 ;^{\mathrm{c}} p<0.001$

closporin group $(r=-0.15$, individual $r$-values: -0.24 $(-0.56$ to 0.20$))$.

Similar inverse correlations could be demonstrated between mean $\mathrm{HbA}_{1 \mathrm{c}}$ at entry, 3, 6, 9 and 12 months [9] and the respective mean $\log _{\mathrm{e}}$ (proinsulin) values in both

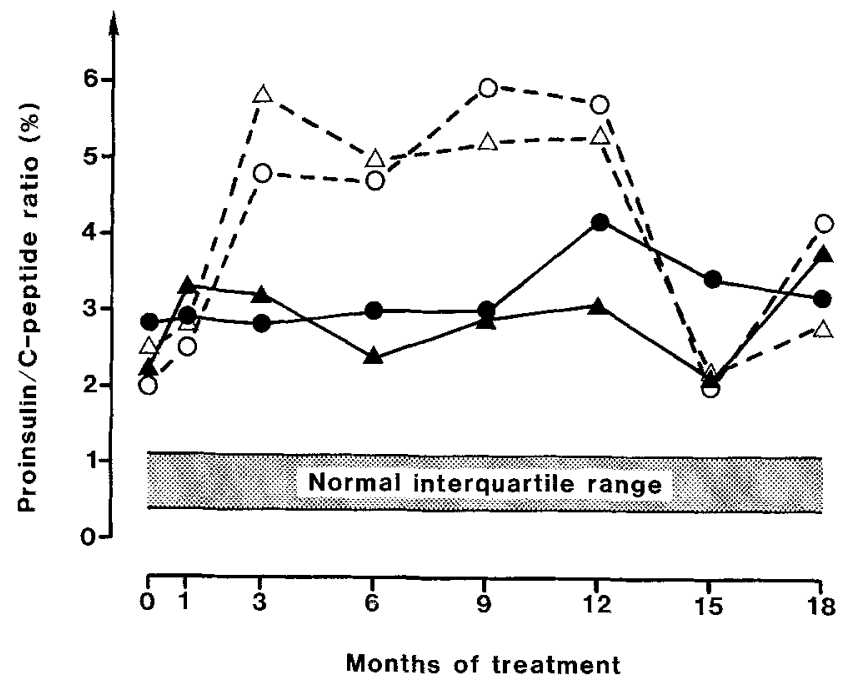

Fig.3. Median fasting proinsulin/C-peptide ratio during 12 months cyclosporin or placebo treatment and 6 months follow-up of respectively, 83 and 86 recent onset Type 1 (insulin-dependent) diabetic subjects either achieving or not achieving non-insulin requiring remission (NIR). Cyclosporin and NIR, $n=44(\bullet)$; cyclosporin without NIR, $n=39$ ( $)$; placebo and NIR, $n=27$ (0---O); placebo without NIR, $n=59(\triangle---\Delta)$

groups (cyclosporin: $r=-0.93$, placebo: $r=-0.93$; $p<0.05$ ) and mean fasting C-peptide values in the cyclosporin-treated group $(r=-0.99, p<0.01)$, but not in the placebo group $(r=-0.22, \mathrm{NS})$. $\mathrm{HbA}_{1 c}$ tended to correlate to $\log _{\mathrm{e}}$ (proinsulin/C-peptide ratio) in the placebo but not in the cyclosporin-treated group; $r=-0.85(p=0.07)$ and $r=-0.18$, respectively.

The HLA-DR3,X positive subjects did not display a further increase of the proinsulin/C-peptide ratio after 1 month of placebo treatment as seen in the rest of the group.

Proinsulin and proinsulin/C-peptide ratio remained significantly lower during the first 6 months in the placebo-treated subjects with a short duration of insulin therapy ( $\leq 14$ days) prior to entry compared to patients with a long duration.

\section{Proinsulin and non-insulin requiring remission (NIR)}

Fifty-four per cent of the cyclosporin-treated subjects participating in the present study acquired a non-insulin requiring state during the first year against $31 \%$ in the placebo group $(p<0.01)$. Proinsulin/C-peptide ratios at each time point in the two groups with or without NIR, are indicated in Figure 3. Cyclosporin had the same impact on the ratio as earlier described, independent of NIR.

The possible value of the ratio at onset in the prediction of remission is illustrated in Table 3. A proinsulin/Cpeptide ratio above 0.024 (median value of all diabetic subjects) at entry to the trial followed by cyclosporin treatment was associated with a frequency of NIR of $64 \%$ against $42 \%$ if the ratio was below $0.024(p=0.077)$. This tendency was not seen in the placebo group. Furthermore, a significant effect of cyclosporin was only present if the 
Table 3. The relationship between the frequency of non-insulin requiring remission (NIR) during the first year of Type 1 (insulin-dependent) diabetes mellitus and fasting proinsulin/C-peptide ratio $(\mathrm{P} / \mathrm{C}$ ratio) at diagnosis in 80 cyclosporin- $(\mathrm{Cy})$ and 81 placebo- $(\mathrm{Pla})$ treated patients. Eight subjects were not included due to missing values at entry. Number of subjects achieving NIR out of the total number in each subgroup are indicated

\begin{tabular}{|c|c|c|c|c|}
\hline & \multicolumn{3}{|c|}{ Treatment } & \multirow[t]{2}{*}{$p$} \\
\hline & $\mathrm{Cy}$ & & Pla & \\
\hline All patients & $43 / 80$ & & $25 / 81$ & $<0.01$ \\
\hline $\begin{array}{l}\mathrm{P} / \mathrm{C} \text { ratio } \geq 0.024 \\
p \\
\mathrm{P} / \text { C ratio }<0.024\end{array}$ & $\begin{array}{l}27 / 42 \\
0.077 \\
16 / 38\end{array}$ & & $\begin{array}{l}11 / 39 \\
\text { NS } \\
14 / 42\end{array}$ & $\begin{array}{l}<0.01 \\
\mathrm{NS}\end{array}$ \\
\hline $\begin{array}{l}\text { HLA-DR } 3,44, \mathrm{X} \text { and } \mathrm{X}, \mathrm{X} \\
\mathrm{P} / \mathrm{C} \text { ratio } \geq 0.024 \\
\dot{p} \\
\dot{\mathrm{P}} / \mathrm{C} \text { ratio }<0.024\end{array}$ & $\begin{array}{l}23 / 35 \\
0.008 \\
9 / 30\end{array}$ & & $\begin{array}{l}10 / 28 \\
\text { NS } \\
10 / 33\end{array}$ & $\begin{array}{l}<0.05 \\
\text { NS }\end{array}$ \\
\hline $\begin{array}{l}\text { HLA-DR } 3, \mathrm{X} \\
\mathrm{P} / \mathrm{C} \text { ratio } \geq 0.024 \\
p \\
\mathrm{P} / \mathrm{C} \text { ratio }<0.024\end{array}$ & $\begin{array}{l}4 / 7 \\
\mathrm{NS} \\
7 / 8\end{array}$ & $0.06^{\mathrm{a}}$ & $\begin{array}{l}1 / 11 \\
\text { NS } \\
4 / 9\end{array}$ & $\begin{array}{l}\mathrm{NS} \\
<0.05^{\mathrm{b}} \\
\mathrm{NS}\end{array}$ \\
\hline
\end{tabular}

${ }^{\mathrm{a}}$ Cy and pla together; ${ }^{\mathrm{b}}$ All Cy vs all pla

ratio was above $0.024(p<0.01)$. Considering the HLA subgroups separately revealed that this association originated from the HLA-DR 3,4 4,X and X,X groups, whereas a low rather than high ratio at entry tended to be related to a higher frequency of remission among HLA-DR 3,X subjects (Table 3 ).

Neither fasting nor glucagon-stimulated C-peptide at entry could predict NIR in either of the treatment groups or in any of the HLA subgroups.

\section{Discussion}

The Canadian/European study of cyclosporin was designed to test the possible effect of the drug on the frequency of remission and C-peptide levels as a measure of B-cell function [9]. No hypothesis concerning proinsulin levels or the proinsulin/C-peptide ratio was suggested beforehand. This must be kept in mind in the evaluation of the present results. Another problem is the large amount of missing values especially during the follow-up period (Table 2). Mainly because of the descriptive nature of the results, we included all patients with available plasma for proinsulin measurements not excluded from the original study. In the choice of statistical methods we have tried to take this into account.

The present study had given evidence for the presence of an altered B-cell function, with a three to fourfold elevation of the molar ratio between fasting proinsulin and C-peptide in recent onset insulin-treated Type 1 diabetic subjects. Thereby, we have substantiated the findings of Ludvigsson [8] and Heding [7]. Furthermore, we have described further changes of $\beta$-cell function during remission and relapse of Type 1 diabetes (placebo group). A plateau-shaped nine months long further elevation of the proinsulin/C-peptide ratio at entry was demonstrated (Fig. 3).
This pattern and the inverse correlation between mean $\mathrm{HbA}_{1 \mathrm{c}}$ at each time point and the respective $\log _{\mathrm{e}}$ (proinsulin) and $\log _{\mathrm{e}}$ (proinsulin/C-peptide ratio) values together with the lack of a "cross sectional" correlation at entry between these parameters, speak against a metabolic "drive" on a reduced number of B cells as the only explanation for the elevated proinsulin/C-peptide ratio in Type 1 diabetes [15]. The finding of elevated proinsulin levels in non-diabetic siblings of Type 1 diabetic subjects further oppose this explanation [16]. The hypothesis, however, is a likely explanation for the observed elevation in poorly controlled Type 2 diabetes $[15,17,18]$. The inverse correlations between proinsulin and both $\mathrm{HbA}_{1 \mathrm{c}}$ and insulin dose in the placebo group suggest that proinsulin may be a better indicator of B-cell function than C-peptide. This is supported by the finding of a significantly lower insulin dose during late remission ( 6 months) compared to shortly after the onset, in spite of similar fasting C-peptide levels (Table 2). The released proinsulin could have some metabolic effects during the late remission. Changes in insulin resistance may, however, be the primary determinant of this phenomenon [19].

Another explanation for the inverse correlation between proinsulin and insulin dose could be a negative feedback control of insulin on proinsulin release, probably through a inhibition of glucagon. A feedback control has been demonstrated in non-diabetic subjects [20], but remains to be studied in Type 1 diabetes.

There is no evidence of a changed metabolic clearance rate of either proinsulin or C-peptide in diabetic subjects [21-23]. Thus, apart from the possible modulating effect of insulin, it seems justified that the plateau-shaped further elevation of proinsulin/C-peptide ratio in the placebo group reflects alterations of B-cell function during remission and relapse.

One could speculate that the relief of the hyperglycaemic drive on the islets makes a partial regeneration of the $B$ cells possible. The ratio between primitive high proinsulin releasing and mature lower proinsulin releasing cells may then increase. The finding of an increased proinsulin to insulin ratio in newborn babies compared to adults supports this theory [24]. Another possibility is the existence of a pool of primitive high proinsulin releasing cells more resistant to destruction.

In the cyclosporin-treated group no elevation of the proinsulin/C-peptide ratio was seen during the remission period, indicating that cyclosporin in some way prevents or delays the further alteration of B-cell function observed in the placebo group during remission. There is evidence suggesting a supressive action of cyclosporin on interleukin-1, which may be an important mediator of B-cell destruction in Type 1 diabetes [25, 26]. Interleukin-1 induces hypoglycaemia in rodents by increasing insulin levels and probably through other, at the moment, unknown mechanisms [27]. A significant part of the measured insulin in this study could have been proinsulin. Thus, a suppression of interleukin-1 may explain why no further increase of proinsulin/C-peptide ratio is observed in the cyclosporin-treated group. The level of the ratio may in 
some way be related to the cytotoxic activity against the $B$ cells.

The association between a proinsulin/C-peptide ratio above 0.024 and the effect of cyclosporin gives, in our opinion no firm guideline for a future therapy, but avocates testing the possible predictive value of the proinsulin/C-peptide ratio in new randomized controlled trials of cyclosporin or other drugs with a possible effect on the frequency of remission.

Renal failure is associated with a decline in clearance and increasing serum levels of C-peptide and proinsulin [28]. Cyclosporin treatment was in the present study associated with a significant decline of calculated creatinine clearance [9], whereas no change was observed in the placebo group. Thus, a cyclosporininduced change of proinsulin clearance cannot explain the effect of cyclosporin on the proinsulin/C-peptide ratio.

Thus, we have confirmed that the proinsulin to C-peptide molar ratio is elevated in recent onset Type 1 diabetic subjects and identified further alterations of B-cell function during remission and relapse with a 9 month long further elevation of the ratio. This pattern is discussed in detail and various hypotheses are proposed. An association between a relatively high proinsulin/C-peptide ratio at entry to the study and a significant effect of cyclosporin on the induction of remission, suggest a possible value of the ratio in the prediction of remission of Type 1 diabetes treated with cyclosporin.

Acknowledgements. We thank the management committee for giving us the opportunity to measure proinsulin and for giving us access to a major part of the collected data. We thank Ms. S. Kjellberg and Ms. J. Falk for skillful technical assistance. The primary study was supported by Sandoz Pharmaceuticals. The following comprises the Canadian/European Diabetes Study Group:

Management Committee

C.R.Stiller, H.Kolb, B. von Graffenried, M.Gent, J.Dupré, J.Nerup and G. Murphy.

Data Centre (not used in the present part of the study)

Robarts Research Institute, London, Ontario, Canada. M.Gent, A. Donner and N.Sommerville

\section{Participating staff}

Canadian centres. Calgary, Alberta. Diabetes: R. G. McArthur and L. Day. Inumunotherapy: J. Klassen. Coordinator: M. Campbell.

Halifax, Nova Scotia. Diabetes: M.H. Tan, S.Salisbury, and S.Shlossberg. Immunotherapy: A.S. MacDonald. Coordinator: J.Salmond.

London, Ontario. Diabetes: J.Dupré, M.Jenner, N.W. Rodger, and J.Mahon. Immunotherapy: C.R. Stiller, P.A. Keown, and D. Heinrichs. Coordinators: J.MacDonald, S. Hayman and H.Sim. Technologists: N. Tchelebi and C. Walter.

Montreal, Quebec. Diabetes: P. Hamet and J. L. Chiasson. Immunotherapy: P. Robitaille. Coordinators: D. Bedard and L. Lotie.

Saskatoon, Saskatchewan. Diabetes: S. VanVliet. Immunotherapy: R. Dyck. Coordinator: S. Rogers.

Vancouver, British Columbia. Diabetes: K.Dawson and W.J. Tze. Immunotherapy: C. E. Reeve. Coordinators: H. Nichol, S. Barrios, and D. Mallory.

Winnipeg, Manitoba. Diabetes: A. Metha. Immunotherapy: J. Jeffrey and D. Rush. Coordinator: S. Beghin.

European centres. Gentofte, Denmark. Diabetes: J.Nerup and T. Mandrup-Poulsen. Immunotherapy: K.Bendtzen, V.Andersen,
E.Kemp and H.Dieperink. Coordinators: H.Espersen, I.Torp, V.Nerup, and H.Nissen. Technologists: M. Munch, U.Soegaard, J.Falk, S. Kjellberg, and E. Schjerning.

Helsinki, Finland. Diabetes: V. Koivisto and Pelkonen. Immunotherapy: M.Leirisalo-Repo and U.Turunen. Coordinators: A. Lehtonen and A.Ojalammi.

Duisseldorf, FRG. Diabetes: F. A. Gries, B. Greulich, and B. Pawlowski. Immunotherapy: B. Grabensee, K. Sprenger, and A. Westhoff. Coordinator: J.Janitz.

Munich, FRG. Diabetes: E.Standl, T.Lander, and H. Mehnert. Immunotherapy: C. Nerl, A.Ziegler, and H. Kolb.

Vienna, Austria. Diabetes: G.Schernthaner, D. Klosch-Kasparek, and G. Aschauer-Treiber. Immunotherapy: C.C. Zielinski and C. Muller.

\section{References}

1. Faber OK, Binder C (1977) B-cell function and blood glucose control in insulin-dependent diabetics within the first month of insulin treatment. Diabetologia 13:263-268

2. Ludvigsson J, Heding L (1978) Beta-cell function in children with diabetes. Diabetes 27 [Suppl.1]: 230-234

3. Agner T, Damm P, Binder C (1987) Remission in IDDM: prospective study of basal C-peptide and insulin dose in 268 consecutive patients. Diabetes Care 10: 164-169

4. Schiffrin A, Suissa S, Poussier P, Guttmann R, Weitzner G (1988) Prospective study of predictors of $\beta$-cell survival in type 1 diabetes. Diabetes 37: 920-925

5. Wallensteen M, Dahlquist G, Persson B, Landin-Olsson M, Lernmark $\AA$, Sundkvist G, Thalme B (1988) Factors influencing the magnitude, duration, and rate of fall of $B$-cell function in Type 1 (insulin-dependent) diabetic children followed for two years from their clinical diagnosis. Diabetologia 31: 664-669

6. Sochett EB, Daneman D, Clarson C, Ehrlich RM (1987) Factors affecting and patterns of residual insulin secretion during the first year of Type 1 (insulin-dependent) diabetes mellitus in children. Diabetologia 30:453-459

7. Heding LG, Ludvigsson J, Kasperska-Czyzykowa T (1981) Bcell secretion in non-insulin and insulin-dependent-diabetics. Acta Med Scand [Suppl.] 659:5-9

8. Ludvigsson J, Heding LG (1982) Abnormal proinsulin/C-peptide ratio in juvenile diabetes. Acta Diabet Lat 19:351-358

9. The Canadian-European randomized control trial group (1988) Cyclosporin-induced remission of IDDM after early intervention: association of $1 \mathrm{yr}$ of cyclosporin treatment with enhanced insulin secretion. Diabetes 37:1574-1582

10. Feutren G, Papoz L, Assan R, Vialettes B, Karsenty G, Vexiau P, Du Rostu H, Rodier M, Sirmai J, Lallemand A, Bach JF (1986) Cyclosporin increases the rate and length of remission in insulin dependent diabetes of recent onset. Lancet II: 119-123

11. Heding LG (1975) Radioimmunological determination of human C-peptide in serum. Diabetologia 11: 541-548

12. Faber OK, Markussen J, Naithani VK, Binder C (1976) Production of anitsera to synthetic benzyloxycarbonyl-C-peptide of human proinsulin. Hoppe Seylers Z Physiol Chem 357: 751-757

13. Hartling SG, Dinesen B, Kappelgård A-M, Faber OK, Binder C (1986) ELISA for human proinsulin. Clin Chim Acta 156: 289-297

14. The Canadian/European Diabetes Study Group. Prepared by: Mandrup-Poulsen T, Mølvig J, Andersen HU, Helquist S, Munck M (1990) Lack of predictive value of islet cell antibodies, insulin autoantibodies, and HLA-DR phenptype for remission in Type I (insulin-dependent) diabetic patients treated with cyclosporin. Diabetes (in press)

15. Gordon P, Hendricks CM, Roth J (1974) Circulating proinsulinlike component in man: increased proportions in hypoinsulinemic states. Diabetologia 10: 469-474

16. Hartling SG, Lindgren F, Dahlqvist G, Persson B, Binder C (1989) Proinsulin is elevated in healthy siblings of insulin de- 
pendent diabetics and independent of HLA identity. Diabetes 38: 1271-1274

17. Glaser B, Leibovich G, Nesher R, Hartling SG, Binder C, Cerasi E (1988) Improved beta-cell function after intensive insulin treatment in severe non-insulin-dependent diabetes. Acta Endocrinol 118: 365-373

18. Yoshioka N, Kuzuya T, Matsuda A, Taniguchi M, Iwamoto Y (1988) Serum proinsulin levels at fasting and after oral glucose load in patients with Type 2 (non-insulin-dependent) diabetes mellitus. Diabetologia 31: 355-360

19. Yki-Järvinen H, Koivisto VA (1986) Natural course of insulin resistance in type I diabetes. $\mathrm{N}$ Eng J Med 316: 224-230

20. Koivisto VA, Yki-Järvinen H, Hartling SG, Pelkonen R (1986) The effect of exogenous hyperinsulinemia on proinsulin secretion in normal man. Obese subjects and patients with insulinoma. J Clin Endocrinol Metab 63: 1117-1120

21. Bergenstal RM, Cohen RM, Lever E, Polonsky K, Jaspan J, Blix PM, Revers R, Olefsky JM, Kolterman O, Steiner K, Cherrington A, Frank B, Galloway J, Rubenstein AH (1984) The metabolic effects of biosynthetic human proinsulin in individuals with type I diabetes. J Clin Endocrinol Metab 58: 973-979

22. Revers R, Henry R, Schmeiser L, Kolterman O, Cohen R, Bergenstal R, Polonsky K, Jaspan J, Rubenstein A, Frank B, Galloway J, Olefsky JM (1984) The effects of biosynthetic human proinsulin on carbohydrate metabolism. Diabetes 33: 762-770

23. Polonsky K, Licinio-Paixao J, Given BD, Pugh W, Rue P, Galloway J, Karrison T, Frank B (1986) Use of biosynthetic human C- peptide in the measurement of insulin secretion rates in normal volunteers and Type I diabetic patients. J Clin Invest 77: 98-105

24. Heding LG, Persson B, Stangenberg M (1980) B-cell function in newborn infants of diabetic mothers. Diabetologia 19: 427-432

25. Nerup J, Mandrup-Poulsen T, MøIvig J, Helqvist S, Wogensen L, Egeberg J (1988) Mechanisms of pancreatic $\beta$-cell destruction in type I diabetes. Diabetes Care 11 [Suppl.1]: 16-23

26. McDaniel M, Hughes JH, Wolf BA, Easom RA, Turk JW (1988) Descriptive and mechanistic considerations of interleukin 1 and insulin secretion. Diabetes 37:1311-1315

27. Rey AD, Besedovsky $\mathbf{H}$ (1987) Interleukin 1 affects glucose homeostasis. Am J Physiol 253: R794-R798

28. Jaspan JB, Mako ME, Kuzuya H, Blix PM, Horwitz DL, Rubinstein AH (1977) Abnormalities in circulating beta cell peptides in chronic renal failure: comparison of $C$-peptide, proinsulin and insulin. J Clin Endocrinol Metab 45: 441-446

Received: 6 April 1989

and in final revised form: 4 September 1989

Dr. O. Snorgaard

Steno Memorial Hospital

Niels Steensensvej 2

DK-2820 Gentofte

Denmark 